\section{Violência física contra \\ menores de 15 anos: estudo \\ epidemiológico em cidade do sul \\ do Brasil}

\author{
Physical abuse of minors under 15: \\ epidemiological study in a city in the \\ south of Brazil
}

Christine Baccarat de Godoy MARTINS'

Maria Helena Prado de MELLO JORGE ${ }^{2}$

${ }^{1} \mathrm{PhD}$ in Public Health by Faculdade de Saúde Pública da Universidade de São Paulo (USP).

${ }^{2}$ Professor of Faculdade de Saúde Pública da Universidade de São Paulo (USP). Department of Epidemiology.

Address: Christine Baccarat de Godoy Martins. Universidade Federal de Mato Grosso, Campus Cuiabá. Nursing Department, Children and Adolescent Health Area. Rua Fortaleza, n 70, Jardim Paulista, Cuiabá (MG), CEP:78065-350. Phone: (65) 36349921. E-mail: leocris2001@terra.com.br mhpjorge@usp.br

\section{Resumo}

Objetivo: apresentar o perfil de casos notificados de violência física contra menores de 15 anos em Londrina, Paraná, no ano de 2006. Método: Estudo transversal, com coleta retrospectiva nos prontuários dos Conselhos Tutelares e serviços de atendimento do município. Os dados foram processados e tabulados pelo programa Epi Info. Resultados: Foram estudados 479 casos de violência por força corporal e 9 casos de violência por outros meios (7 por instrumentos, 1 por objeto cortante e 1 por substância corrosiva). Na violência por força corporal, predominaram vítimas do sexo feminino $(53,4 \%)$ e maior risco na idade de seis anos (12,2 por 1.000). O pai foi o agressor mais freqüente $(48,8 \%)$ e o alcoolismo esteve presente em $64,0 \%$ dos casos. A violência por instrumentos foi praticada através de cinta (42,9\%), fio $(28,6 \%)$, ferro $(14,3 \%)$ e instrumento de cozinha $(14,3 \%)$, com vítimas do sexo feminino $(85,7 \%)$, na faixa etária de doze anos (33,3\%), sendo o pai $(71,4 \%)$ e a mãe $(28,6 \%)$ os únicos agressores, com o alcoolismo presente em $57,1 \%$ destas situações. A vítima de violência por objeto cortante era do sexo masculino, 13 anos e o agressor, desconhecido, tinha de 15 a 19 anos. A violência por substância corrosiva teve como vítima um adolescente de 13 anos, do sexo masculino, cujo agressor foi o pai, sendo o alcoolismo a situação presente. Conclusões: Os resultados apontam para a importância epidemiológica do abuso físico contra crianças e adolescentes e podem contribuir para a elaboração de estratégias de prevenção e acompanhamento das vítimas.

Palavras-chave:Violência; Maus-Tratos; Agressão Física; Abuso Físico; Criança; Adolescente. 


\section{Abstract}

Objectives: to build the epidemiological profile of deliberate violence against minors under 15 years of age in Londrina, Paraná in 2006. Methods: cross-sectional study with retrospective data collected from the records of Tutelary Councils and care services in the city. Data were processed and tabulated with Epi Info software. Results: 479 cases of violence by use of physical force and 9 cases of violence by others means ( 7 by instruments, 1 by cutting object and 1 by corrosive substance) were studied. Most victims of physical force were female (53.4\%) and the highest risk age was 6 (12.2 per 1,000). The father was the main aggressor $(48.8 \%)$ and alcoholism was present in $64.0 \%$ of cases. Violence by instrument was inflicted with belt $(42.9 \%)$, wire $(28.6 \%)$, iron (14.3\%), or kitchen tool (14.3\%), mainly with $85.7 \%$ female victims in the 12 yearold age group (33.3\%). Father $(71.4 \%)$ and mother $(28.6 \%)$ were the only aggressors, with alcoholism present in $57.1 \%$ of the situations. The victim of violence with a cutting device was a 13 year-old male, the aggressor was unknown and between 15 and 19 years of age. Violence by a corrosive substance victimized a male adolescent aged 13. The aggressor was the alcoholic father. Conclusion: outcomes point toward the epidemiological importance of physical abuse of children and adolescents, and can contribute to structure strategies to prevent child abuse and follow-up victims.

Keywords: Violence; Maltreatment; Physical Aggression; Physical Abuse; Child; Adolescent.

\section{INTRODUCTION}

Violence against children and adolescents has been standing out in morbidity and mortality statistics in several countries, and has been acknowledged as a major public health problem ${ }^{(1-9)}$.

Among the many types of violence, physical abuse has been mentioned, in different countries, as a major cause, due to the severity of lesions and consequences they bring forth, in addition to the considerable expenditures in care and consequences to the child and family ${ }^{(8-13)}$.

Several studies have identified physical abuse as the most frequent maltreatment against children and adolescents ${ }^{(4,11,14-18)}$. Physical force as an educational method and cultural acceptance of punishment as something necessary for children make physical aggression in our environment frequent $^{(3,19-21)}$.

In relation to victims, it is not only a matter of thinking of the physical consequences subsequent to striking, slapping, kicking, punching, among others, but also of the several sequelae that begin the longer the period of abuse. In addition to physical sequelae that cause pain and stress, the fact that a child still does not have the psychological structure, and the constant state of alert due to the presence of maltreatment may lead to emotional, affective and psychological sequelae. Many of these sequelae, irreparable and significant to the child's health, manifest themselves in adult life. They include anxiety and depression, risk of self-destruction, low self-esteem, pessimistic vision of the world, relationship problems, aggressiveness, shyness, social isolation, submission, attention deficit, hyperactivity, low cognitive and language capacity, alcohol and drug abuse, in addition to abusive behavior that contributes to upholding violence ${ }^{(9,12,14,20,22-27)}$.

Despite the increase in scientific production in the area, advances in Brazilian legislation as to the rights of children and adolescents, and the mandatory reporting of these events by professionals directly 
linked to children and adolescents, is still underestimated in our country. According to some authors, of 10 to 20 cases of physical abuse, only one case is reported ${ }^{(9)}$.

Toward this end, the present a set of cases aimed to illustrate the profile of cases of physical violence against minors under 15 reported in Londrina, Paraná, in 2006, so as to contribute to the epidemiological knowledge of the event in children and adolescents.

\section{METHODS}

The survey was cross-sectional and descriptive on physical violence against minors under 15, during 2006 and reported to the Tutelary Councils of the city of Londrina (Center, North and South) and services for victimized children and adolescents in the city (Sentinel Program of Londrina City Hall and the De Olho No Futuro Project). Services mentioned are all the existing ones for assisting children and adolescents victims of violence in Londrina.

At the above mentioned services, all records and all forms related to services rendered to minors under 15 were seen, and the cases of physical violence selected. Cases included represent the total number of cases reported in the city. Data were transferred to a specific form and contained information on the accusation, the victim, the violent act and the aggressor. The tool was previously tested and used for collecting data by a team of students of the Nursing course of Universidade Estadual de Londrina, previously trained and supervised by a one of the authors of the study.

All data were processed electronically and computed using the Epi Info - version $6.04 \mathrm{~d}_{\text {program }}^{(28)}$. Data were checked by verifying inconsistencies and errors in the analyses performed. Duplicate records of the same violent act, for example, in the case of a child seen at two services, were considered as only one case, in order to calculate the number of violent acts and not of services rendered. Analyses were based only on the description of the frequencies related to the features assessed.

The directors or individuals responsible for each institution were requested to authorize access to records and information. The research project was analyzed by the Ethics in Research Committee of Universidade de São Paulo, and approved (COEP 315 de 2006).

Given the differences among types of physical violence regarding characteristics of victims, analysis was performed separately for two groups: violence by physical force and physical violence by other means (including violence by instruments, cutting devices or corrosive substances). Scherer and Scherer ${ }^{(29)}$ have classified physical violence as direct (practiced by kicking, slapping, pinching, spanking, punching, etc.) and indirect (exerted by means of instruments). For Pires and Miyazaki ${ }^{(26)}$ physical violence includes pinching and hitting with a slipper, to ear pulling, slapping, punching, kicking, hitting with a belt, burning with hot water or cigarette tip or electric iron, intoxication with narcotics, suffocation, mutilation, and beating. Gomes ${ }^{(30)}$ also distinguishes physical force aggression from physical aggression by cutting weapons, cutting devices or firearm projectiles. In this sense, the classification used by the authors justifies the detailed analysis in the present study, according to different types of physical aggression.

The incidence rate for cases of violence by physical force was calculated using the number of children resident of the city, in the same age group and year as the denominator, given the case studied referred to the total number of cases reported in the city.

Only sequelae registered in the records were considered, based on the assessment of the Tutelary Counselor that accompanied the case.

As to the circumstances present in the violence (such as alcoholism, unemployment, etc.), data were collected systematically from all sources from which information was obtained. 


\section{RESULTS}

\section{Violence by use of physical force}

Violence by physical force totaled 479 cases in 2006, which represents $98.1 \%$ of physical violence. Accusations were made by mother $(24.4 \%)$ or other relatives such as uncle/aunt, sister-in-law, cousin or sibling (20.9\%), and neighbors or school (17.1\% each), grandparent (10.6\%), health professional $(4.2 \%)$, anonymous $(4.0 \%)$, parent $(0.8 \%)$, community $(0.2 \%)$, or other $(0.2 \%) ; 0.4 \%$ of records did not contain the information.

Among victims, the proportion of females was higher (53.4\%) than males (46.5\%), with a sex ratio of 0.9 or, 1.1 girls per each boy.

Incidence rates of violence by physical force per age group and sex of victims showed the highest risk at age six for both sexes (11.3 per 1,000 for boys and 13.2 per 1,000 for girls). The general rate points toward a higher risk for the six-year-old age group (12.2 per 1,000$)$. Reduction in physical ag- gression as of eleven years of age for both sexes was also observed, however with a smaller decline for females (Figure 1).

Most aggressors were males (72.6\%), and $38.8 \%$ were between 30 and 40 years old (Table 1). Among female aggressors, the 20 to $24(28.2 \%), 30$ to $34(25.2 \%)$ and 25 to 29 years $(22.9 \%)$ age groups stand out.

Fathers were the most common aggressor by physical force $(48.8 \%)$, followed by stepfathers $(21.1 \%)$, mothers $(14.8 \%)$, stepmothers (11.1\%), or other relatives (1.5\%), which means that $97.3 \%$ of aggressors are family members (Table 2). Other aggressors include educational entities $(0.8 \%)$, neighbors $(0.6 \%)$, nannies $(0.4 \%)$, mother's boyfriends $(0.2 \%)$, and unknown $(0.2 \%)$.

Alcoholism prevailed among situations related to maltreatment by physical force, with a proportion of $64.0 \%$, although marital crises (15.7\%), drug addiction (1.5\%) and unemployment (1.3\%) were also present. Other situations present and not informed totaled $17.6 \%$ (Table 2). Marital crisis stands out when the mother is the aggressor

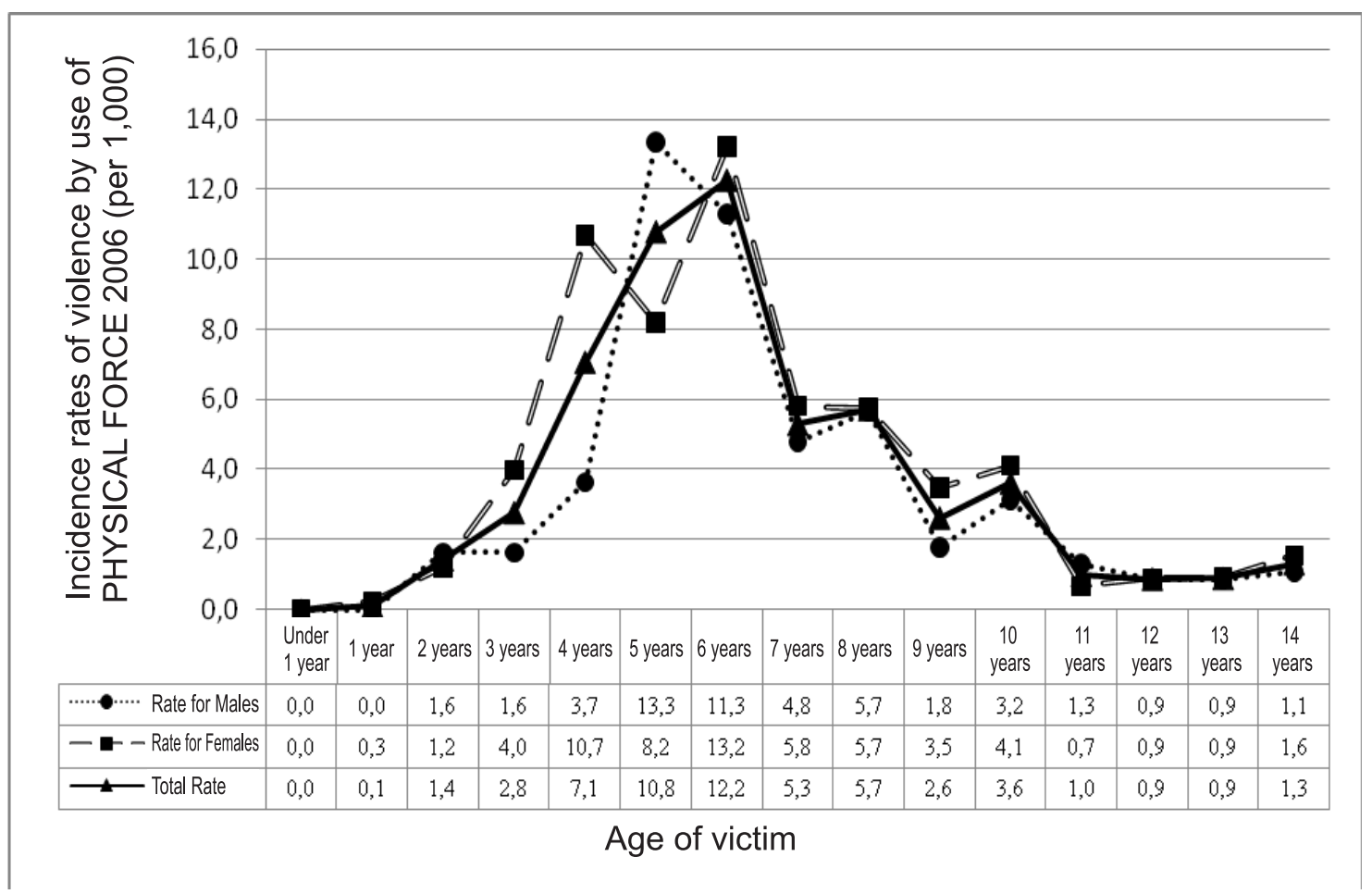

Figure 1 - Incidence rates of violence by use of PHYSICAL FORCE against minors under 15 years of age per sex and age of victims. Londrina, 2006. 
Table 1 - Cases of violence by use of PHYSICAL FORCE against minors under 15 years of age per age and sex of aggressor. Londrina, 2006.

\begin{tabular}{lcccccc}
\hline \multirow{2}{*}{$\begin{array}{l}\text { Age of aggressor of violence by } \\
\text { PHYSICAL FORCE }\end{array}$} & \multicolumn{7}{c}{ SEX OF AGGRESSOR } \\
\cline { 2 - 8 } & Male & \multicolumn{7}{c}{ Female } & \multicolumn{3}{c}{ TOTAL } \\
\cline { 2 - 7 } & $\#$ & $\%$ & $\#$ & $\%$ & $\#$ & $\%$ \\
\hline$>15$ & 9 & 2.6 & 2 & 1.5 & 11 & 2.3 \\
15 to 19 & 2 & 0.6 & 1 & 0.8 & 3 & 0.6 \\
20 to 24 & 8 & 2.3 & 37 & 28.2 & 45 & 9.4 \\
25 to 29 & 40 & 11.5 & 30 & 22.9 & 70 & 14.6 \\
30 to 34 & 135 & 38.8 & 33 & 25.2 & 168 & 35.1 \\
35 to 39 & 110 & 31.6 & 22 & 16.8 & 132 & 27.6 \\
40 and over & 41 & 11.8 & 5 & 3.8 & 46 & 9.6 \\
Unknown & 2 & 0.6 & - & - & 2 & 0.4 \\
Not Informed & 1 & 0.3 & 1 & 0.8 & 2 & 0.4 \\
\hline TOTAL & $\mathbf{3 4 8}$ & $\mathbf{1 0 0 . 0}$ & $\mathbf{1 3 1}$ & $\mathbf{1 0 0 . 0}$ & $\mathbf{4 7 9}$ & $\mathbf{1 0 0 . 0}$ \\
\hline
\end{tabular}

Table 2 - Cases of violence by use of PHYSICAL FORCE against minors under 15 years of age per link between aggressors / victims and situation present in the circumstances of the violence. Londrina, 2006.

\begin{tabular}{|c|c|c|c|c|c|c|c|c|c|c|c|c|}
\hline \multirow{3}{*}{$\begin{array}{l}\text { Link between } \\
\text { Aggressor and } \\
\text { Victim } \\
\text { Relatives }\end{array}$} & \multicolumn{12}{|c|}{ Situation present in circumstances of violence } \\
\hline & \multicolumn{2}{|c|}{ Alcohol Abuse } & \multicolumn{2}{|c|}{ Drug Addiction } & \multicolumn{2}{|c|}{ Unemployment } & \multicolumn{2}{|c|}{ Marital Crisis } & \multicolumn{2}{|c|}{ Not Informed } & \multicolumn{2}{|c|}{ TOTAL } \\
\hline & $\#$ & $\%$ & $\#$ & $\%$ & $\#$ & $\%$ & $\#$ & $\%$ & $\#$ & $\%$ & $\#$ & $\%$ \\
\hline Mother & 7 & 9.9 & - & - & - & - & 64 & 90.1 & - & - & 71 & 14.8 \\
\hline Father & 212 & 90.6 & 2 & 0.9 & 4 & 1.8 & - & - & 16 & 6.8 & 234 & 48.8 \\
\hline Stepfather & 83 & 82.2 & 4 & 4.0 & 2 & 2.0 & - & - & 12 & 11.9 & 101 & 21.1 \\
\hline Stepmother & 2 & 3.8 & - & - & - & - & 11 & 20.8 & 40 & 75.5 & 53 & 11.1 \\
\hline Other relatives & 3 & 42.9 & - & - & - & - & - & - & 4 & 57.1 & 7 & 1.5 \\
\hline Neighbors & - & - & - & - & - & - & - & - & 3 & 100.0 & 3 & 0.6 \\
\hline Unknows Person & - & - & - & - & - & - & - & - & 1 & 100.0 & 1 & 0.2 \\
\hline Educational Entity & - & - & - & - & - & - & - & - & 4 & 100,0 & 4 & 0.8 \\
\hline Mother's boyfriend & - & - & 1 & 100.0 & - & - & - & - & - & - & 1 & 0.2 \\
\hline Nanny & - & - & - & - & - & - & - & - & 2 & 100.0 & 2 & 0.4 \\
\hline Unknown & - & - & - & - & - & - & - & - & 2 & 100.0 & 2 & 0.4 \\
\hline TOTAL & 307 & 64.0 & 7 & 1.5 & 6 & 1.3 & 75 & 15.7 & 84 & 17.6 & 479 & 100.0 \\
\hline
\end{tabular}

(90.1\%) and alcoholism when the father is the aggressor $(90.6 \%)$ as is also the case of a stepfather $(82.2 \%)$.

Violence by physical force occurred, predominantly, at the victim's home (95.6\%), with very few cases at school (1.0\%), aggressor's house $(1.3 \%)$, relative's house $(0.2 \%)$ or in the street $(1.7 \%)$; and in $0.2 \%$ of cases the information was unknown.

Most victims were submitted to violence by physical force for four or more times (93.\%) before reporting; and it was for the first time in $2.9 \%$, the third time in $1.5 \%$, and the second time, in $0.8 \%$ of the cases, while the information could not be found in $0.8 \%$ of records. 
Victims of this kind of violence were being submitted to abuse for 1 to 2 years $(47.0 \%)$, followed by those who were being submitted to the aggravation for 3 to 4 years $(28.4 \%)$, over 4 years $(16.5 \%)$, less than 6 months (4.4\%) and from 6 to 12 months (1.7\%). The information could not be determined in $0.8 \%$ of records.

All cases of aggression by physical force in minors under 15 years of age resulted in body lesions. However, the constraints for determining the kind and nature of the lesion based on the records prevented the analysis of severity.

Violence by physical force affected several regions (54.5\%), followed by upper (16.5\%) and lower (15.7\%) limbs. Head $(0.8 \%)$, trunk $(2.1 \%)$ and abdomen/back/ pelvis $(10.0 \%)$ were the body parts least affected by physical aggression.

The lack of information as to the need for hospitalization in $96.6 \%$ of records prevents the analysis of the variable, although it was one of the initial aims of the present study.

Cases with sequelae represented $99.8 \%$ (478 cases); $99.6 \%$ of these were physical and $0.4 \%$ psychological sequelae. It is important to point out that the present investigation, considered the sequelae in records registered by tutelary councilors, whose scientific knowledge frequently is insufficient for determining the presence and nature of sequelae. There were records of a second sequela, with a predominance of psychological (98.1\%).

\section{Other means of physical violence}

In addition to violence by use of physical force, seven cases of violence inflicted by instruments were reported, chiefly with anonymous accusations (42.9\%), affecting mainly female victims (85.7\%), and with higher number of cases in the twelve years age group (five cases) among girls, followed by ages 2, 7, 8 and 9 years (one case in each age). The only male case occurred with an eight year old. Most aggressors were males $(71.4 \%)$, whose most frequent age was 30 to 34 years $(60.0 \%)$. Among women who practiced violence using instruments, the highest proportion was in the 20 to 24 years age group $(100.0 \%)$. Either a father $(71.4 \%)$ or mother $(28.6 \%)$ were single aggressors. Alcoholism was present in $57.1 \%$ of cases, although the highest proportion of records in which the information could not be collected (42.9\%) compromised the analysis of the variable. All cases occurred at victims' homes; they had suffered the aggression four or more times before the accusation $(100.0 \%)$, and for periods over 4 years (42.9\%) before being reported. Instruments used were belts $(42.9 \%)$, wire $(28.6 \%)$, iron (14.3\%) and kitchen utensils (14.3\%). All victims presented lesions, mainly in lower limbs (57.1\%), although the nature and severity could not be determined. Many records (87.1\%) did not have information on the need for hospitalization, and the remaining $12.9 \%$ did not need to be hospitalized. There were physical sequelae in $100.0 \%$ of cases, all accompanied by psychological sequelae.

Only one case of violence by a cutting device was reported in the study year, and whose victim was a 13 year old boy. The male aggressor, whose connection to the victim was unknown, was in the 15 to 19 years age group. The case happened on the street and it was the first time the victim had suffered violence. The lesion affected the chest, with need for hospitalization, and there were physical and psychological sequelae.

A corrosive substance was used to practice violence also in a single case of a 13-year-old male adolescent as the victim. The aggressor (his own father) was in the 35-to-39-year-old group and reported alcoholism. Violence was practiced at the victim's home, for the first time, with burns in multiple regions, need for hospitalization and physical and psychological sequelae.

\section{DISCUSSION}

The results from the present set of cases are restricted to the characteristics of the cases of physical violence against minors under 15 years, during 2006, reported to Tutelary Councils and services that assist children 
and adolescents in the city. The design of the present investigation (case study) does not permit describing associations between violence and potential risk factors. As it is a cross-sectional study, the characteristics presented refer to a specific moment, and may change as interventions are introduced.

Few studies analyze aggression by physical force in detail, and perform the analysis along with physical violence or, even, as a global analysis of all types of violence. A study performed in a service in the city of Curitiba found the community as the main accuser of physical abuse (85.8\%), mainly neighbors and healthcare professionals ${ }^{(9)}$. Another study that also analyzed physical aggression against children and adolescents registered at Rio de Janeiro police stations, observed that $53.0 \%$ of accusations were made by policemen ${ }^{(31)}$. Data from CLAVES (Fundação Oswaldo Cruz's Latin-American Center of Studies on Violence and Health), reveal that those who most frequently inform physical aggression against children and adolescents are mothers and military police $^{(30)}$. However, such studies do not distinguish aggression by physical force from other types of physical violence, which compromises comparison of results.

The participation of school, mother, relatives and neighbors reporting aggression by physical force shows the visibility of this kind of violence, given it leaves marks that are perceived by those close to the child, as for example, the accusers mentioned above. In turn, when the accusation comes from the mother, even if she is the aggressor, it may mean a cry out for help, given the lesions due to physical aggression make the diagnosis of violence easier and trigger immediate measures to protect the child.

Slightly different from our study, other studies have observed that the age group most submitted to physical aggression were five to eleven year-olds ${ }^{(9)}$, albeit very little difference in terms of percentage between victims' sex (50.2\% male and $49.8 \%$ female), result similar to the present study. In a study developed at the Maltreatment Outpatient Clinic - Ambulatório de Maus-Tratos of the city of Caxias do Sul ${ }^{(14)}$, on the other hand, boys were observed to be submitted more to physical violence than girls while data collected at the Niterói Tutelary Council ${ }^{(32)}$ detected little difference between sex when considering physical violence. When analyzing victims of aggression, some authors conclude that sex is not a variable that determines the occurrence of maltreatment, among children and adolescents ${ }^{(33)}$.

The predominance of the four to six years age group in physical aggression reported and referred to services is justifiable due to the physical and psychological dependence, of children in this age group.

What stands out in the present study is the reduction in physical aggression as of eleven years of age, which may be related to the growth and development of children who acquire strength and means to defend themselves as they get older. For girls, the lower decline in physical aggression after eleven years may be related to the physical fragility of the gender and dependence upon the aggressor.

Similar to the present set of cases, a study performed based on records of Rio de Janeiro police stations revealed more male aggressors (78.0\%) among cases of physical aggression against children and adolescents $^{(31)}$. The higher proportion of male aggressors in this kind of violence may be related to the physical strength attributed to males since the beginning of time ${ }^{(34)}$.

No studies determining ages of aggressors were found. However, the prevailing age observed for physical force aggressors (30 to 34 years for males and 20 to 24 years for females) match the fact they are in the age group that may have children and may use physical punishment to educate. The little participation of older aggressors strengthens the assumption above.

The literature review showed some results different from those found in the present investigation. In the study of Assis and Souza ${ }^{(31)}$, although parents were among aggressors, the main individual responsible for physical aggression against children and adolescents were neighbors, although 
the source is police station records. In turn, records from the Curitiba SOS Criança-SOS Child verified that the mother, most of the time, using her own hands, was the aggressor in $42.2 \%$ of cases of physical abuse against children ${ }^{(9)}$. However, other studies have revealed that a major part of physical violence is inflicted by the father ${ }^{(9,15)}$. In this scenario, it is necessary to point out that culturally, the father figure is associated with authority and imposing limits, which may contribute to the occurrence of physical force inflicted by fathers.

Similar to what was observed in the present investigation, alcoholism is appointed out by domestic and international authors as a factor present in violent circumstances against children and adolescents ${ }^{4,9,}, 26,14-15$ 35). Marital crisis as a scenario for physical aggression was also reported by a study that highlights family conflict associated with use of alcohol as the core for physical violence at home ${ }^{(30)}$.

Rarely do studies specify the site of occurrence of physical aggression. Given that main aggressors in physical violence by physical force are the parents, naturally this kind of violence occurs very frequently at victims` homes. As homes should be a place for protecting and caring for children, but silently harbor the violence against them ${ }^{(36-37)}$, the need to prioritize prevention to develop non violent values and general awareness in the fight against physical aggression stands out.

The frequency of violence by physical force observed in the present study corroborates the discussion that violence is not restricted to a single episode. In face of this fact and taking into account that physical aggression leaves more evident marks than other forms of violence, appropriate mechanisms for detecting and intervening on this kind of aggression are necessary, because for several authors, the suspicion and appropriate intervention is the first step for interrupting the suffering children and adolescents are being submitted to ${ }^{(6,31)}$. In this way, a study with employees in the pediatrics unit of a university hospital in
Finland revealed the $60.0 \%$ of interviewees (physicians and nurses) needed training in order to identify child abuse, in addition to each one's difficulties in dealing with violence against children ${ }^{(38)}$.

The long period of abuse points toward the possibility of consequences, appointed by some authors as irreparable in many situations ${ }^{(9)}$. Specifically in relation to physical aggression, one should not think only of the physical consequences subsequent to moves, slaps, kicks, punches, among others, but also on the several sequelae that occur the longer the period of abuse ${ }^{(27)}$.

Other studies have shown the presence of hematoma as the most frequent lesions in physical aggression ${ }^{(9)}$, as well as ecchymoses, cuts, scratches and excoriations ${ }^{(8)}$. However, some authors draw attention to the severity of lesions due to physical aggression, such as lethal skull fractures and trauma $^{(10-13)}$, in addition to the considerable expenses for care and the consequences to the child and family.

Sanchez and Minayo ${ }^{(39)}$ appointed that the most frequent lesions by physical aggression are cutaneous-mucosa (due to moves, burns, pulling teeth and hair, bites, and by cutting weapons or firearms, varying from hyperemia, ecchymosis, hematoma, to third degree burns), fractures of different levels of severity, head trauma, intra-cerebral hemorrhage due to shaking and impacts, and eye and ear lesions that may lead to temporary or permanent disability.

It should be pointed out, however, that frequently, only the most severe cases are reported, which may have contributed to the high rate of body lesions herein present. Although the present study was not able to determine the severity of lesions, based on the literature, the severity of lesions subsequent to physical aggression, appointed by several authors as temporary or permanent, with significant consequences to children's health, should be taken into account.

The results found are in agreement with a study developed at the Curitiba SOS Criança ${ }^{(9)}$, in which the great majority lesions resulting from physical abuse affected 
more than one body segment (64.9\%). The authors of the study state that the type of lesion and the body segment affected in the physical aggression depend on the age of the child, according to how children manage to protect themselves from aggression. In a study by Assis and Souza ${ }^{(31)}$, physical aggression affected limbs (42.0\%), head (36.0\%), trunk $(26.0 \%)$ and multiple regions $(8.0 \%)$, but these lesions resulted from battery in $53.0 \%$ of cases, that is, more severe cases registered at Rio de Janeiro police stations.

The fact that aggressions by physical force affect more than one body segment shows the great exposure of victims or, still, the inability to defend themselves.

Some studies highlight the direct repercussion of violence on demand for medical care, as, for example, orthopedic and skull trauma, dislocations and fractures resulting from physical abuse ${ }^{(10)}$. Still to be considered in this context are the cases of unperceived violence and that are hospitalized as accidental injury. Therefore, victims of physical aggression (that generate immediate physical lesions) may demand much more hospital and medical care than what is actually acknowledged.

Authors consider that sequelae of physical violence may vary from temporary to permanent scars and deformities ${ }^{(6)}$, in addition to medium and long term emotional, psychological and affective sequelae ${ }^{(10)}$. Unfortunately, due to the quality of information, it was not possible to determine the severity and extension of the sequelae present in the set of cases, but it is possible to agree with the authors above, based on the observation of a high frequency of physical and psychological sequelae in the population victim of physical aggression.

Studies specifically analyzing aggression by instruments were not found, because most of the work classifies this kind of aggression with physical aggression, which made comparison of results difficult.

However, it is possible to think that the greater participation of neighbors and anonymous accusers may be related to the greater severity and repulsiveness of vio- lence inflicted through instruments. In this aspect, some authors highlight the severity of aggression by other means subsequent to the utilization of objects, such as belts, pieces of wood and iron bars, among others ${ }^{(10)}$. These means may draw more attention than the use of physical force, motivating accusations by individuals outside the family core, such as neighbors, for example. The high proportion of anonymous accusers may be related to fear of involvement, given they are more violent aggressions than by use of physical force.

Unlike aggression by physical force, in which there was a major difference between males and females, in aggression by other means the great predominance of females among victims stands out. Moreover, the age group of victims is observed to be above eleven years of age. Such event reflects the fact that instruments are used as children grow older and are able to defend themselves from physical force violence. The predominance of girls may be explained by the gender's own vulnerability, given boys over eleven already have the ability to defend themselves. The presence of a case of a two year old (inflicted by the father using a wire, accused by a neighbor) also stands out. Considering that in this phase children are completely defenseless, the cruelty of the aggressor should be highlighted. No similar studies were located for the purpose of comparison.

The age group of aggressors in violence by instruments remained similar to the analysis of violence by physical force, whose previous discussion may be applied to these results. The predominance of male aggressors strengthens the discussion on the use of violence by men ${ }^{(31)}$, as the relationship of domination of the stronger over the weaker ${ }^{(34)}$.

In a study with children victims of physical aggression, authors also observed that mothers were the most frequent aggressors, using their own hands and instruments ${ }^{(9)}$. Based on the records of the Niterói Tutelary Council, in turn, the authors observed the father as the main participant in physical 
violence ${ }^{(32)}$. Despite the methodological differences between both studies (the first collected data at a service for victimized children and the second at the Tutelary Council), the predominance of parents as main aggressors is in agreement with several domestic and international authors who point out violence practiced by parents as a sad reality of our society $(3,6,8,12,14-14,26,36,40-41)$.

In this way, it is necessary to think about and work family relations, with programs that have the family as their intervention target, making relations between health services and the community closer, and making it easier to identify families at risk for violence and enable interdisciplinary practice. According to the scholars on the topic, it is also necessary to use existing legislation and disclose the penalties subsequent to such practice in order to change behaviors and the concept that domestic violence is a forum exclusive to the family ${ }^{(11)}$.

Many authors point out that use of alcohol seems to contribute to all kinds of violence ${ }^{(9,36)}$, but this also cannot be analyzed alone, given violence is generated by multiple factors associated among themselves ${ }^{(26)}$.

It is interesting to observe that aggression by another specified mean followed the same pattern of violence by physical force regarding site of occurrence, corroborating the previous discussion on domestic violence. This behavior of violence by specified means corroborates the discussion that it is necessary to create awareness on the importance of information and intervention, because the fact that many professionals state it is not a health issue, strengthens the recurrence of maltreatment even more ${ }^{(31)}$.

Studies specifying the period of abuse in this kind of violence were not found. However, the period and abuse observed match the period of abuse verified in aggression by physical force, reaffirming the silent and insidious aspect of the violence.

Some of the means verified in the present study are appointed by other authors as common to physical violence ${ }^{(26)}$ and match those observed among physical aggressions practiced against children seen at the Curitiba SOS Criança, which revealed the utilization of belts, wood, shoes, rubber, among other objects ${ }^{(9)}$. In this aspect, scholars relate the several instruments utilized in the aggression with the severity of subsequent trauma, and need for hospitalization and, even, with death ${ }^{(10)}$. In face of the fact, it is possible to conclude that violence by other means results in relevant physical consequences, pointing toward the need for effective prevention and intervention measures in order to avoid and interrupt suffering and risks inflicted on children victim of this kind of aggression, and reduction in sequelae.

The lack of information on the need for hospitalization in records made the analysis of severity of this kind of event difficult, as well as the direction of specific measures, making evident the need to improve quality of information.

Taking into account the previous discussion on the severity of lesions and body segments affected by this kind of violence, added to total physical and psychological sequelae observed in the present study, the importance of this event, despite the few cases observed, should be pointed out.

After an exhaustive literature review, it was not possible to find studies analyzing aggression by a cutting device. The exclusive predominance of male adolescents and the young age of aggressors stand out, and may show the immaturity of aggressors and, maybe the characteristic behavior of boys who get involved in fights. The low frequency and short period of abuse observed shows that the exposure to this kind of violence was sporadic, without showing the chronic nature of the event, as observed in the analysis of violence by physical force. The presence of a lesion, physical sequela and need for hospitalization point toward the severity of the event, that when affecting noble areas of the trunk, risks the health of victims.

Even after an extensive reference review, no data on aggression by corrosive substance were found in the literature. Despite a sole case registered, the severity 
of the subsequent lesion stands out, and, despite the victim being old enough to defend himself from physical aggression, it may have not been possible to avoid the aggression by corrosive substance, given it can be launched against the victim even at a certain distance. The scars certainly left by this kind of aggression contribute even more to psychological sequelae, present in the case studied. Like in other aggressions, alcoholism appears in the circumstances of the violent act, highlighting the need for attention to this factor. In this sense, Gomes et al ${ }^{(42)}$ point out the association between alcoholism and psychological factors, which demand more in depth studies on the issue.

\section{CONCLUSION}

Based on the results, it is possible to point out the epidemiological importance of physical abuse against children and adolescents, which is an expressive public health issue to be faced by preventive and therapeutic measures, given lesions and consequences of the events. The findings, by detailing characteristics and circumstances of events may contribute to the development of strategies to prevent and control the condition.

In face of the complexity and circumstances of physical violence against minors, there is a pressing need for joint actions between the health sector, other public sectors and civil society, to design actions to prevent and deal with the situation.

The need for research and studies that may contribute to the knowledge of this important condition in the child-juvenile population also stands out. We should also emphasize the importance of monitoring these events and conducting new in-depth studies on the issue in order to contribute to its prevention and treatment.

\section{REFERENCES}

1. Bazon MR. Maus-tratos na infância e adolescência: perspectiva dos mecanismos pessoais e coletivos de prevenção e intervenção. Ciência \& Saúde Coletiva 2007; 12(5): 1110-27.

2. Costa IER, Ludermir AB, Avelar I. Violência contra adolescentes: diferenciais segundo estratos de condição de vida e sexo. Ciência \& Saúde Coletiva 2007; 12(5): 1193-200.

3. Carmo CJ, Harada MJCS. Violência física como prática educativa. Rev. Latino-am Enfermagem 2006; 14(6): 17 25 .

4. Vizcarra MB, Cortés J, Bustos L, Alarcón M, Muñoz S. Maltrato infantil em La ciudad de Temuco. Estudio de prevalência y fatores asociados. Ver Méd Chile 2001; 129(12): 1425-32.

5. Marmo DB, Davoli A, Ogido R. Violência doméstica contra a criança (Parte I). J. Pediatr. (Rio J.) 1995; 71(6): 313-6.

6. Marmo DB. A violência doméstica contra a criança. Temas de Pediatria Nestlé 1999; 68: 5-32.

7. Pordeus AMJ, Fraga MNO, Faço TPP. Ações de prevenção dos acidentes e violências em crianças e adolescentes, desenvolvidas pelo setor público de saúde de Fortaleza, Ceará, Brasil. Cad. Saúde Pública 2003; 19(4): 1201-4.
8. Trocmé N, MacMillan H, Fallon B, Marco RD. Nature and severity of physical harm caused by child abuse and neglect: results from the Canadian Incidence Study. CMAJ 2003; 169(9): 911-5.

9. Pascolat G, Santos CFL, Campos ECR, Valdez LCO, Busato D, Marinho DH. Abuso físico: o perfil do agressor e da criança vitimizada. J. Pediatr (Rio J.) 2001; 77(1): 3540 .

10. Reichenheim ME, Hasselmann MH, Moraes CL. Conseqüências da violência familiar na saúde da criança e do adolescente: contribuições para a elaboração de propostas de ação. Ciência \& Saúde Coletiva 1999: 4(1): 109-121.

11. Lopes MVG, Tavares Jr PA. Maus-tratos: 57 observações em enfermaria. Pediatria Moderna 2000; 36 (10): 684-8.

12. Hijar-Medina M, Flores-Regata L, Valdez-Santiago R, Blanco J. Atención médica de lesiones intencionales provocadas por la violência familiar. Rev. Salud Pública de México 2003; 45(4): 252-8.

13. Fong CM, Cheung HM, Lau PY. Fractures associated with non-accidental injury: an orthopaedic perspective in a local regional hospital. Hong Kong Med J 2002; 11(6): 445-51.

14. De Lorenzi DRS, Pontalti L, Flech RM. Maus tratos na infância e adolescência: análise de 100 casos. Rev. Cient. AMECS 2001; 10(1): 47-52. 
15. Brito AM, Zanetta DM; Mendonça RC; Barison SZ, Andrade VAG. Violência doméstica contra crianças e adolescentes: estudo de um programa de intervenção. Ciência e Saúde Coletiva 2005; 10(1): 143-9.

16. Moura ATMS, Reichenheim ME. Estamos realmente detectando violência familiar contra a criança em serviços de saúde? A experiência de um serviço público do Rio de Janeiro, Brasil. Cad. Saúde Pública 2005; 21(4): 1124-33.

17. Weber LND, Viezzer AP, Brandenburg OJ, Zocche CRE. Famílias que maltratam: uma tentativa de socialização pela violência. Psico-USF 2002; 7(2): 163-73.

18. Creighton SJ. Prevalence and incidence of child abuse: international comparisons. NSPCC Information Briefings. April 2004. [citado 2008 Fev. 20]. Disponível em: www.nspcc.org.uk/ Inform/OnlineResources/InformationBriefings / PrevalenceAndIncidenceOfChildAbuse_asp_ ifega26028html.

19. Shnit D. Proteção de crianças contra a violência: aspectos legais. In: Westphal MF (org). Violência e Criança. São Paulo: Editora da Universidade de São Paulo (EDUSP); 2002. p. 143-65.

20. Brenes RG. La prevencion del abuso físico contra los niños y niñas menores de cinco anos de edad. Acta Pediátr. 2001; 15(3): 1-13.

21. Mc Alister A, Sandstrom P, Puska P, Veijo A, Chereches R, Heidmets LT. Attitudes towards war, killing and punishment of children among young people in Estonia, Finland, Romania, the Russian Federation, and the USA. Bulletin of the World Health Organization 2001: 79(5): 382-7.

22. Grilo CM, Masheb RM. Childhood psychological, physical, and sexual maltreatment in outpatients with binge eating disorder: frequency and associations with gender, obesity, and eating-related psychopathology. Obesity Research 2001; 9(5): 320-5.

23. Assis SG, Constantino P. Violência contra crianças e adolescentes: o grande investimento da community acadêmica na década de 90. In: Minayo MCS (organizadora). Violência sob o olhar da saúde: infrapolítica da contemporaneidade brasileira. Rio de Janeiro: Editora Fiocruz; 2003. p. 163-89.

24. Arcos E, Uarac M, Molina I. Impacto de la violencia domestica e la salud infantil. Rev. Med Chile 2003; 131: 1454-62.

25. Assis SG, Avanci JQ, Santos NC, Malaquias JV, Oliveira RVC. Violência e representação social na adolescência no Brasil. Rev Panam Salud Publica 2004; 16(1): 43-51.

26. Pires ALD, Miyazaki MCOS. Maus-tratos contra crianças e adolescentes: revisão da literatura para profissionais da saúde. Arq Ciênc Saúde 2005; 12(1): 42-9.
27. Chalk R, Gibbons A, Scarupa HJ. The multiple dimensions of child abuse and neglect: new insights into an old problem, 2002. [citado 2008 Fev. 20]. Disponível em: http//www.Childtrends.org/files/ChildAbuseRB.pdf

28. Dean AG, Dean JA, Coulombier D, Brendel KA, Smith DC, Burten AH, Dicker RC, Sullivan K, Fagan RF, Arner TG. EPI INFO version 6: word processing, database and statistics program for epidemiology on microcomputers. Centers for Disease Control and Prevention, Atlanta, USA; 1995.

29. Scherer EA, Scherer ZAP. A criança maltratada: uma revisão da literatura. Rev. Latino-am. Enfermagem 2000: 17(3): 521-31.

30. Gomes R. Da denúncia à impunidade: um estudo sobre a morbi-mortalidade das crianças vítimas de violência. Cad. Saúde Pública 1998; 14(2): 301-11.

31. Assis SG, Souza ER. Morbidade por violência em crianças e adolescentes do município do Rio de Janeiro. J Pediatr (Rio J.) 1995; 71(6): 303-12.

32. Cavalcanti MLT. Estudo Descritivo dos Registros de Violência Doméstica no Conselho Tutelar de Niterói. Cad. Saúde Coletiva 1999; 7(1): 99-123.

33. Gomes R, Silva CMFP, Njaine K. Prevenção à violência contra a criança e o adolescente sob a ótica da saúde: um estudo bibliográfico. Ciência e Saúde Coletiva 1999; 4: 171-81.

34. Minayo MCS. O significado social e para a saúde da violência contra crianças e adolescentes. In: Westphal MF (org). Violência e criança. São Paulo: Editora da Universidade de São Paulo (USP); 2002. p.95-114.

35. Guerra RDO. Abuso sexual em ninas y ninos consideraciones clínicas. J Pediatr 2000; 76(4): C33-C38.

36. Roque EMST, Ferriani MGC. Desvendando a violência doméstica contra crianças e adolescentes sob a ótica dos operadores do direito na Comarca de Jardinópolis SP. Rev. Latino-am Enfermagem 2002; 10(3): 334-44.

37. Ricas J, Miguir TVD, Mona LMG. A violência na infância como uma questão cultural. Texto Contexto Enferm (Florianópolis) 2006; 15(1): 151-4.

38. Paavilainem E, Astedt-Kurki P, Paunonem-Ilmonem M, Laippala P. Caring for maltreated children: a challenge for health care education. Advanced Nursing 2002; 37(6): 551-7.

39. Sanchez RN, Minayo MCS. Violência contra crianças e adolescentes: questão histórica, social e de saúde. In: Ministério da Saúde. Violência faz mal à saúde / [Cláudia Araújo de Lima (coord) et al]. - Brasília: Ministério da Saúde, 2004. p.29-38.

40. Minayo MCS. Violência contra crianças e adolescentes: questão social, questão de saúde. Rev. Bras. Saúde Mater-infant (Recife) 2001: 1: 91-102. 
41. Theodore AD, Chang JJ, Runyan DK, Hunter WM, Bangdiwala SI, Agans R. Epidemiologic Features of the Physical and Sexual Maltreatment of Children in the Carolinas. Pediatrics 2005; 115(3): 331-7. [citado 2008 Fev. 20]. Disponível em <http//: www.pediatrics.org $>$.
42. Gomes R, Deslandes SF, Veiga MM, Bhering C, Santos JFC. Por que as crianças são maltratadas? Explicações para a prática de maus-tratos infantis na literatura. Cad. Saúde Pública 2002; 18(3): 707-14. 